\title{
Vamos Program-Technological Innovation for Behavior Change for Older Adults in the Brazil- ian Unified Health System
}

\author{
Tânia Bertoldo B*, Tomicki C and Konrad LM
}

Laboratory of Studies of Environmental Behavior Change and Aging (LAMCE) linked to the Center for Physical Activity and Health Research (NUPAF) of the Federal University of Santa Catarina, Brazil

ISSN: 2578-0093

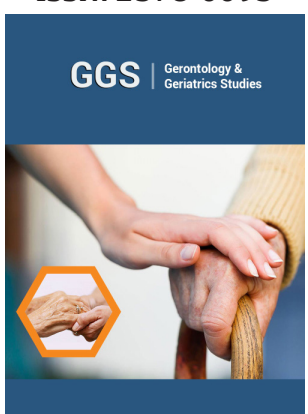

*Corresponding author: Tânia Bertoldo Benedetti, Laboratory of Studies of Environmental Behavior Change and Aging (LAMCE) linked to the Center for Physical Activity and Health Research (NUPAF) of the Federal University of Santa Catarina, Brazil.

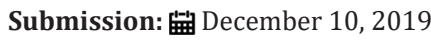

Published: 制 December 16, 2019

Volume 5 - Issue 4

How to cite this article: Tânia Bertoldo B, Tomicki C, Konrad L. Vamos ProgramTechnological Innovation for Behavior Change for Older Adults in the Brazilian Unified Health System. Gerontol \& Geriatric stud.5(4). GGS.000616.2019. DOI: 10.31031/GGS.2019.05.000616

Copyright@ Tânia Bertoldo Benedetti, This article is distributed under the terms of the Creative Commons Attribution 4.0 International License, which permits unrestricted use and redistribution provided that the original author and source are credited.

\section{Abstract}

Keywords: Older adults; Public health; Behavior change; Health promotion; Lifestyle

\section{Opinion}

Population aging is a global phenomenon. This transition is occurring faster in developing countries and it comes with epidemiological changes. Very complex changes have been observed in health-disease models and are currently experiencing a high prevalence of chronic noncommunicable diseases (NCDs) [1]. NCDs represent one of the biggest threats to health and development worldwide (representing $71 \%$ of causes of death), especially in developing countries such as Brazil (representing 74\% of causes of death) [2-4]. The trend of population aging requires the broad and diverse management of NCDs [5]. Therefore, public policies have been invested to support actions to change the lifestyle of the population [6]. In the Brazilian context, most of these actions are a set of educational activities and programs implemented by the Unified Health System (SUS) [7] directed to promoting physical activity and healthy eating [8-10].

The aging of society brings both opportunities and challenges for many low- and middleincome countries like Brazil. A new paradigm in health needs to be adopted, one that focuses on prevention and management of chronic disease through healthy lifestyle strategies designed to maintain independent living and promote quality of life. In addressing this complex public health care challenge. There is a need to bring community resources together and utilize it in systems that focus on health habits. Public health centers are an example of community health strategy sponsored by the government. Most of health services provided by the public health centers focuses on primary health care and prevention programs focusing on healthy lifestyles are increasingly being offered to communities [11].

In recent years research suggests that incorporating a comprehensive behavioral management strategy is important for maintaining the quality of life of the older age citizens. VAMOS Program was developed by researchers of the Laboratory of Studies of Environmental Behavior Change and Aging (LAMCE in the Portuguese acronym) linked to the Center for Physical Activity and Health Research (NuPAF in the Portuguese acronym) of the Federal University of Santa Catarina. VAMOS is based on the logic model of behavior change and the socio cognitive theory of Bandura et al. [12]. The aim of VAMOS is to motivate people to adopt an active and healthy lifestyle by engaging in physical activity and healthy eating habits [13]. The program provides autonomy to its participants, offering educational experiences. It is intended for people aged at 18 years old or older, users of the Basic Health Units. It is offered in 12 face-to-face meetings held weekly, totaling an active phase of three months and a maintenance phase of 12 months. The meetings provide opportunities of interactions between the provider and the participants and are conducted by staff members of the public health centers with the help of specialized health teams. The meetings have a duration of 90 to 120 minutes. The goals (individual and group) proposed to the participants are developed at each meeting. Short-, medium- and long-term goals are crafted on these meetings. For 
implementation of the program (SUS) staff underwent the "Training of the VAMOS Program" free of charge through Distance Learning, with a workload of 20 hours [14] per week. Details of the VAMOS Program can be found in the logic model developed by Benedetti et al. [13] and at the site of the program (https://vamos.ufsc.br/).

The VAMOS program has been tested in the public health care system since 2012 with 326 older adults, mostly female $(87.7 \%)$ with an average age of 68.3 years $( \pm 6.7)$. To evaluate the effectiveness of the program, the level of physical activity, food consumption, weight loss and perception of quality of life are used as markers. Results showed a reduction in sedentary behavior, an increase in light physical activity, a 10\% increase in the time spent on physical activity with moderate/vigorous intensities, lower consumption of industrialized foods, increased consumption of raw vegetables and reduction of $0.5 \mathrm{~kg}$ of average body mass, besides the increase in the perception of quality of life $[11,15,16]$.

a) This program has been advancing in the Brazilian health care system. In 2017 there was a restructuring of the program with an online version, and an increase from 12 to 18 sections, made to be completed in nine months. This version is being implemented in southern Brazil and will complement research on behavior change of elderly in the country. Considering the global context of NCDs and the need for sustainable public health interventions, the VAMOS Program is an innovative technology to be used in the Unified Health System as a strategy for behavioral changing, related to physical activity and nutrition in the elderly.

\section{References}

1. Mendes EV (2018) The care for chronic conditions in primary health care. Rev Bras Promoc Saúde 31(2): 1-3.

2. WHO (2018) Global health estimates 2016: deaths by cause, age, sex, by country and by region, 2000-2016? Geneva: World Health Organization.

3. WHO (2018) World health statistics 2018: Monitoring health for the SDGs, sustainable development goals? Geneva: World Health Organization

4. WHO (2018) Noncommunicable diseases (NCD) country profiles 2018? Geneva: World Health Organization.
5. WHO (2018) Time to deliver: report of the WHO independent highlevel commission on noncommunicable diseases? Geneva: World Health Organization.

6. WHO (2017) Noncommunicable diseases progress monitor 2017? Geneva: World Health Organization.

7. Brasil (2017) Portaria no 2.436, de 21 de setembro de 2017-Aprova a Política Nacional de Atenção Básica, estabelecendo a revisão de diretrizes para an organização da Atenção Básica, no âmbito do Sistema Único de Saúde (SUS). Brasília: Ministério da Saúde.

8. Becker LA, Gonçalves PB, Reis RS (2016) Programas de promoção da atividade física no Sistema Único de Saúde brasileiro: revisão sistemática. Rev Bras Ativ Fís Saúde 21(2): 110-122.

9. Ramos LR, Malta DC, Gomes GAO, Bracco MM, Florindo AA, et al. (2014) Prevalence of health promotion programs in primary health care units in Brazil. Rev. Saúde Pública 48(5): 837-844.

10. Sá GBAR, Dornelles GC, Cruz KG, Amorim RCA, Andrade SSCA, et al. (2016) O programa academia da saúde como estratégia de promoção da saúde e modos de vida saudáveis: cenário nacional de implementação. Ciênc. saúde coletiva 21(6): 1849-1859.

11. Benedetti TRB, Rech CR, Konrad LM, Almeida FA, Brito FA, et al. (2019) Re-thinking physical activity programs for older Brazilians and the role of public health centers: a randomized controlled trial using the RE-AIM model. Frontiers in Public Health.

12. Bandura A (1986) Social foundations of thought and action: A social cognitive theory. Prentice-Hall, Englewood Cliff, New Jersey, USA.

13. Benedetti TRB, Manta SW, Gomez LSR, Rech CR (2017) Logical model of a behavior change program for community intervention-active life improving health-let's go. Rev Bras Ativ Fís Saúde 22(3): 309-313.

14. José HPM, Konrad LM, Ribeiro CG, Benedetti TRB (2019) Validação do treinamento para multiplicadores do programa Vida Ativa Melhorando a Saúde (VAMOS). Journal of Physical Education 30(e3040): 1-11.

15. Gerage AM, Benedetti TRB, Dias RM, Santos ACO, Souza BCC, et al. (2017) Effectiveness of a behavior change program on physical activity and eating habits in patients with hypertension: a randomized controlled trial. J Phys Act Health 14(12): 943-952.

16. Meurer ST, Lopes ACS, Almeida FA, Mendonça RD, Benedetti TRB (2019) Effectiveness of the VAMOS strategy for increasing physical activity and healthy dietary habits: a randomized controlled community. Health Educ Behav 46(3): 406-416. 